revealed issues which are vitally important to the control of reproduction. The animal collections maintained by the Society at Regent's Park and Whipsnade constitute the richest assemblies of living vertebrates in the world, and the Society also has in its possession breeding records which go back to the year 1828. The resources of the Society, however, have never been sufficient to promote a proper and continuing investigation of breeding behaviour.

Those appointed to the research fellowships, of which there will be six-three senior and three junior fellowships--will be expected to undertake systematic studies of the reproductive habits and the physiology of animals. It is hoped that they will have a secondary attachment to a university department or to a research institute in which reproductive physiology is a major research interest. Laboratories will be provided at Regent's Park by the Zoological Society, and a Breeding Research Committee, including British scientists who are in the forefront of research into reproductive physiology, has been established to supervise the work. Among those serving on the Committee are Prof. E. C. Amoroso, Prof. F. W. Rogers-Brambell, Prof. A. St. G. Huggett and Dr. A. S. Parkes.

\section{The Beit Memorial Fellowships}

THE trustees of the Beit Memorial Fellowships for medical research have announced the following elections: Junior Fellowships ( $\$ 900$ a year), D. C. Watts, to study the mechanism of enzymes in muscle from animals of various species and especially the role of the sulphydryl groups thought to be necessary for enzyme activity (at the Department of Biochemistry, University College, London); J. R. Casley-Smith, to investigate the ultra-structure and properties of the endothelium of lymphatics, in health and disease, with special reference to dropsy (at the Sir William Dunn Sehool of Pathology, Oxford) ; P. F. Fottrell, to investigate the mechanism of adaptive enzyme formation in normal and malignant animal cells maintained in tissue culture (at the Tissue Culture Laboratory, Biochemistry Department, University of Glasgow); A. J. Rowe, to study the properties of the contractile muscle protein myosin, by means of the electron microscope (at the Department of Colloid Science, Cambridge) ; Dr. G. F. V. Seaman, to study the relationship between the chemical composition of the human red blood corpuscle membrane and its electrokinetic charge as determined by microelectrophoresis (at the Department of Medicine, Cambridge). Senior Fellowship ( $£ 1,300$ a year), Dr. J. R. Tata, to purify and isolate thyroxine dehalogenase from various tissues and to investigate the relationship between metabolic transformation of thyroid hormones and their action in an isolated system (at the National Institute for Medical $R_{\theta}$ search, Mill Hill, London).

\section{Paul Instrument Fund Awards}

Awards of grants by the Paul Instrument Fund Committee have been made as follows : $£ 2,500$, with the probability of further grants totalling up to $£ 3,000$, to Dr. J. H. Sanders, university lecturer and demonstrator in physics, Clarendon Laboratory, Oxford, for the construction of an optical maser ; $£ 3,000$ to Mr. H. W. Gosling, lecturer in the Department of Engineering, University College of Swansea, for the construction of an instrument for checking the stability of the standard ampere. The Paul Instrument Fund Committee, composed of repre- sentatives of the Royal Society, Physical Society. Institute of Physics and Institution of Electrica] Engineers, was set up in 1945 "to receive applications from British subjects who are research workers in Great Britain for grants for the design, construction and maintenance of novel, unusual or much improved types of physical instruments and apparatus for' investigations in pure or applied physical science".

\section{Co-operative Research in Europe}

A shorT article, "O.E.E.C. and the Scientific Future", in the February issue of European Pro. ductivity notes some of the ways in which the Organization for European Economic Co-operation has been strengthening the scientific resources of Europe. First, the Organization is pursuing an inquiry into the scientific policies of member countries and their research resources, such as a study of fiscal measures which influence investment in industrial research. Secondly, co-operative research is in progress on fatigue failure in metals and the fouling of ships' hulls; representatives from Sweden and Yugoslavia joined the group of experts this year and the adhesion of Yugoslavia will make it possible to secure a better picture of fouling organisms in Mediterranean waters. Tests are still being made in Europe, Australia, North America, South Africa and Singapore, and a catalogue of the biological and hydrological characteristics of the testing stations in use will be published. Experts from nine European countries and the United States have met to plan co-operative research into aircraft noise and have recommended free exchange of all available informa. tion on aircraft noise and its effects, particularly its biological effects on people living near airports. A permanent group has been set up to advise the Committee on Applied Research on the long-term development of research into the abatement of aircraft noise. A group of nine member countries dealing with fire research is proposing to study unstable chemicals for plastics and also fire-fighting techniques and materials, while other work is in hand on the industrial utilization of oil-shale fires, the measurement of air pollution, static electricity in industrial tools, road safety and production engineering techniques. Thirdly, attention is being given to the supply of scientific and technical personnel in relation to Europe's economic needs, including such matters as the use of television in science teaching, and methods of teaching mathematics in schools.

\section{British Library of Political and Economic Science}

THE annual report of the British Library of Political and Economic Science for 1958-59 records little change in the funds available for purchase or in book prices; but acquisitions of Russian publications were slightly lower than in 1957-58 and were facilitated by exchange arrangements with the Saltykor-Shchedrin Public Library, Leningrad, the Lenin Library, Moscow, and the All-Union Library of Foreign Literature (pp. 16. London: British Library of Political and Economic Science, 1959). Additions during the year included 5,330 treatises, 1,510 pamphlets, 2,386 non-serial government publications and 8,235 current serials, including 5,913 periodical titles received as gifts from governments, municipalities, institutions and societies. Of the Library's total holdings of 401,752 bound volumes, 12,137 were in the Lending Library and 4,674 in the Shaw Library. 